\title{
Inseverability Clauses in Statutes
}

\author{
Israel E. Friedman†
}

When holding a statutory provision unconstitutional, a court must determine whether to sever the defective provision or to invalidate the entire statute. In order to guide courts, lawmakers often include a severability clause ${ }^{1}$ in legislation. The clause instructs a court that has held portions of a statute invalid to sever the invalid statutory provisions from the rest of the statute and to allow the statute's valid sections to remain operative. ${ }^{2}$ Less frequently, a statute will include an inseverability clause ${ }^{3}$ that invalidates an entire statute (or section of a statute) should a provision be held invalid. ${ }^{4}$ In part because severability clauses have become boilerplate, these clauses have had little effect on courts making severability determinations.

Despite the explicit statutory language in severability and inseverability clauses, courts all but ignore the clauses and apply their own tests and presumptions to determine severability. ${ }^{5}$

$\dagger$ B.A. 1993, Columbia College; J.D. Candidate 1998, The University of Chicago.

2 They are also known as separability clauses.

2 See, for example, 8 USC \$ 1101 (Section entitled "separability") (1988 \& Supp 1996), quoted in INS $v$ Chadha, 462 US 919, 932 (1983) ("If any particular provision of this Act, or the application thereof to any person or circumstance, is held invalid, the remainder of the Act and the application of such provision to other persons or circumstances shall not be affected thereby.").

3 These clauses are occasionally referred to as non-severability clauses, unseverability clauses, reverse severability clauses, non-separability clauses, or inseparability clauses.

4 See, for example, 42 USC § 300aa-1 (1994):

(a) In General. Except as provided in subsection (b), if any provision [of] part A or B of subtitle 2 of title XXI of the Public Health Service Act [subparts A and B of part 2 of this subchapter], as added by section 311(a), or the application of such a provision to any person or circumstance is held invalid by reason of a violation of the Constitution, both such parts shall be considered invalid.

and 25 USC \$ 941(m) (1994):

(a) Severability. If any provision of section $941 \mathrm{~b}(\mathrm{a}), 941 \mathrm{c}$ or $941 \mathrm{~d}$ of this title is rendered invalid by the final action of a court, then all of this subehapter is invalid. Should any other section of this subchapter be rendered invalid by the final action of a court, the remaining sections of this subchapter shall remain in full force and effect.

See also 25 USC \$\$ 1734, 1749(1), 1760 (1988 \& Supp 1996); 2 USC $\$ 1221$ (1994), repealed by Pub L No 104-1, 109 Stat 41 (1995).

- See generally Mark L. Movsesian, Severability in Statutes and Contracts, $30 \mathrm{Ga} \mathrm{L}$ Rev 41 (1995); John Copeland Nagle, Severability, 72 NC L Rev 203 (1993); Robert L. 
These tests generally begin with a presumption that all statutes are either severable or inseverable, ${ }^{6}$ usually followed by an examination of the particular statute's structure and legislative history in order to determine whether the remainder of the statute would be consistent with the legislative intent. ${ }^{7}$ Courts will also consider whether the statute can reasonably function as an autonomous whole without the invalid provision. ${ }^{8}$

This approach provides scant guidance to courts faced with a severability question, often leaving them to speculate about what the legislature intended to accomplish in passing the statute and whether that purpose is frustrated by the provisions invalidated. This is remarkable in light of the clear instructions provided by inseverability (and severability) clauses that would appear to resolve this very issue.

This Comment argues that inseverability clauses are fundamentally different from severability clauses and should be shown greater deference than their sister severability clauses. Part I discusses the courts' approach to severability and inseverability clauses. Part II examines the assumptions behind the courts' treatment of severability clauses and criticizes the application of those principles to inseverability clauses. Part III argues that, with some exceptions, courts should defer to the plain language of inseverability clauses. It also attempts to place the proposed rule within the current debate over statutory interpretation.

\section{DECIDING WHETHER TO SEVER INVALID STATUTORY PROVISIONS}

\section{A. Severability Clauses: A Mere Presumption}

The Supreme Court established the general standard for determining whether an invalid provision is severable from the rest of a statute in Champlin Refining Co $v$ Corporation Commission

Stern, Separability and Separability Clauses in the Supreme Court, 51 Harv L Rev 76 (1937).

- Compare Regan v Time, 468 US 641, 653 (1984) (establishing a presumption of severability), with United States House of Representatives v Federal Trade Comm'n, 463 US $1216,1218 \mathrm{n}$ * (1983) (White dissenting), citing Carter $v$ Carter Coal Co, 298 US 238, 312 (1936) (establishing a presumption of inseverability when a statute does not include a severability clause).

7 See, for example, Regan, 468 US at 653 ("Whether an unconstitutional provision is severable from the remainder of the statute in which it appears is largely a question of legislative intent, but the presumption is in favor of severability.").

${ }^{8}$ See, for example, Alaska Airlines v Brock, 480 US 678, 684 (1987) ("Congress could not have intended a constitutionally flawed provision to be severed from the remainder of the statute if the balance of the legislation is incapable of functioning independently."). 
of Oklahoma..$^{9}$ Faced with a state oil drilling statute containing potentially unconstitutional price controls, the Court had to consider whether the overall statutory scheme could survive a challenge to the pricing provisions. The Champlin Court refused to defer to the statute's severability clause and required instead that a court look at the structure of a statute to determine severability. The Court held that "[u]nless it is evident that the legislature would not have enacted those provisions which are within its power, independently of that which is not, the invalid part may be dropped if what is left is fully operative as a law."10 In effect, this established a presumption of severability that could be rebutted if a court determined that the legislature did not intend for the statute to exist without the invalid provision. This required courts to speculate as to what the legislative intent behind the statute was at the time of its passage and what it would be after the provision was held invalid. Although a statute's severability clause would seem to provide evidence of legislative intent, the Court in United States $v$ Jackson stated that "the ultimate determination of severability will rarely turn on the presence or absence of such a clause."11 Thus, by including a severability clause, a legislature does little more than spill ink since the clause has a minimal bearing on the severability determination.

Similarly, in INS $v$ Chadh $a,{ }^{12}$ the Court, after holding that the legislative veto provision of the Immigration and Nationality Act was unconstitutional, considered whether the provision was severable from the rest of the statute. Although the Act contained a severability clause, the Court again was unwilling simply to rely on the statute's own provision to determine severability. The Court chose instead to examine the legislative history of the Act, and severed the unconstitutional provision only after concluding that the congressional intent in the legislative record supported such a holding. ${ }^{13}$

286 US 210 (1932).

${ }^{10}$ Id at 234.

"11 390 US 570, 585 n 27 (1968).

${ }^{12} 462$ US 919 (1983).

${ }^{13}$ Id at 931-35. Because of the large number of statutes containing legislative veto provisions, the Chadha Court's unwillingness to consider the severability clause dispositive brought severability questions to the fore. Compare Glenn C. Smith, From Unnecessary Surgery to Plastic Surgery: A New Approach to the Legislative Veto Severability Cases, 24 Harv J Leg 397, 399 (1987) (criticizing presumption of severability in legislative veto cases), with Note, Severability of Legislative Veto Provisions: A Policy Analysis, 97 Harv L Rev 1182, 1194-95 (1984) (arguing for severability of legislative veto provisions). See also William Alan Shirley, Note, Resolving Challenges to Statutes Containing Unconstitutional Legislative Veto Provisions, 85 Colum L Rev 1808, 1820 (1985) (arguing that 
The Court, in Alaska Airlines, Inc $v$ Brock, ${ }^{14}$ further explained that, far from being dispositive; a severability clause creates no more than a mere presumption of severability. The presumption can be overcome if legislative history and the statute's structure indicate that the statute would not have been passed without the invalid provision. ${ }^{15}$

Similarly, several state courts often begin with a presumption of severability that can be overcome by legislative intent. Many of these courts have second-guessed plain statutory language and have held statutory provisions inseverable despite the presence of severability clauses. ${ }^{16}$ One court aptly described the caselaw's indifference to the plain language of severability clauses as "a narrow exception to the general rule that, when a clause is unambiguous, construction is unnecessary."17 The plain meaning of a severability clause unambiguously instructs a court to uphold the remainder of a statute. However, in the realm of severability, plain meaning does not prescribe the result, and the clause is all but ignored while the court makes an independent determination of legislative intent by construing legislative history and statutory structure.

Acknowledging the ineffectiveness of severability clauses, some states have actually codified rules of construction for interpreting severability questions that arise under their codes. ${ }^{18}$ These statutes reflect the caselaw's indifference to severability clauses. Pennsylvania's statute, for example, provides for a presumption that all of the state's statutes are severable, regardless of whether they include a severability clause or not. ${ }^{19}$ This pre-

the question of the propriety of severability turns on the type of statute involved).

14480 US 678 (1987).

${ }^{15} \mathrm{Id}$ at 686.

${ }^{16}$ See, for example, Fumarolo $v$ Chicago Board of Education, $142 \mathrm{Ill} 2 \mathrm{~d} 54,566 \mathrm{NE} 2 \mathrm{~d}$ 1283,1303 (1990) (finding statute inseverable despite presence of a severability clause because "the legislature would not have enacted this statute" without the invalid provision); Inganamort $v$ Borough of Fort Lee, 131 NJ Super 558, 330 A2d 640, 645 (1974) (finding statute inseverable despite severability clause because invalid provision was an inducement for the passage of the law); Lynden Transportation, Inc $v$ State, 112 Wash $2 \mathrm{~d}$ 115, 768 P2d 475, 480 (1989) (“[A] severability clause will not save other portions of the act if the court nonetheless decides that the Legislature probably would not have passed the remaining portion of the act without the invalid part or if we believe that the remaining valid enactment would not reasonably accomplish the legislative purpose.").

${ }^{17}$ Stiens $v$ Fire and Police Pension Assn, 684 P2d 180, 184 n 12 (Colo 1984) (en banc).

${ }^{13}$ See, for example, Md Ann Code Art 1, \$ 23 (Michie 1996); Minn Stat Ann $\$ 645.20$ (West 1947). See also Nagle, $72 \mathrm{NC} L \mathrm{Rev}$ at 256-57 (cited in note 5) (advocating adoption by legislatures of such rules of construction).

$191 \mathrm{~Pa}$ Stat $\$ 1925$ (Purdon 1995) provides:

The provisions of every statute shall be severable. If any provision of any statute or the application thereof to any person or circumstance is held invalid, the remainder 
sumption can be overcome, however, if a court finds that the legislature would not have passed the statute absent the invalid clause or that the remainder of the statute cannot function properly without the invalid provision.

\section{B. Inseverability Clauses: A Mirror Image?}

Research uncovered no reported opinions in which a federal court has interpreted an inseverability clause in a federal statute, perhaps because there are so few of these clauses. When faced with an inseverability clause in a state statute, however, federal courts have applied the same analysis they apply to severability clauses-examining legislative intent, legislative history, and the statute's ability to function without the invalid portion before accepting the plain meaning of the inseverability clause. ${ }^{20}$ In Biszco $v$ RIHT Financial Corp, ${ }^{21}$ for example, the First Circuit held that the analysis applied to the severability clause in Chadha was equally applicable to an inseverability clause in a Rhode Island statute. ${ }^{22}$ Thus, inseverability clauses establish no more than a presumption of inseverability that courts may overcome after an examination of legislative intent.

State courts have also imported the rule for interpreting severability clauses to inseverability clauses. In Stiens $v$ Fire and Police Pension Association, ${ }^{23}$ for example, the Supreme Court of Colorado first held that a portion of the Colorado Policemen's and

of the statute, and the application of such provision to other persons or circumstances, shall not be affected thereby, unless the court finds that the valid provisions of the statute are so essentially and inseparably connected with, and so depend upon, the void provision or application, that it cannot be presumed the General Assembly would have enacted the remaining valid provisions without the void one; or unless the court finds that the remaining valid provisions, standing alone, are incomplete and are incapable of being executed in accordance with the legislative intent.

The statute was applied in Commonwealth Dept of Education v The First School, $471 \mathrm{~Pa}$ 471,370 A2d 702, 705 (1977).

${ }^{23}$ Although a severability determination of a state statute is a matter of state law, Leavitt $v$ Jane L., $116 \mathrm{~S} \mathrm{Ct} 2068,2069$ (1996), courts often overlook the Erie question and apply a general common law of statutory interpretation. See, for example, Brookins $v$ O'Bannon, 699 F2d 648, 650-51, 655 (3d Cir 1983) (looking beyond inseverability clause to legislative history before holding the statute inseverable); Rebaldo v Cuomo, 1984 WL 48826, *10 (S D NY) (noting that the statute's importance and purpose militate against adopting the literal construction of the inseverability clause), vacated on other grounds, 749 F2d 133 (2d Cir 1984).

${ }^{21} 758$ F2d 769, 773-74 (1st Cir 1985), affirming 102 FRD 538, 543 (D RI 1984).

${ }^{22}$ Biszco, 758 F2d at 773-74, affirming 102 FRD at 543 ("A severability or, in this case non-severability, clause is a guideline for a statutory interpretation but not a mandate to the court[.]").

${ }^{23} 684$ P2d 180 (Colo 1984) (en banc). 
Firemen's Pension Reform Law was an unconstitutional retroactive law because it mandated pension fund contributions to cover liabilities accrued before the statute's passage. Although the law contained an inseverability clause, the court was reluctant to follow it: "The special unseverability clause . . . is not conclusive as to legislative intent. It gives rise only to a presumption that, if the unconstitutional parts of an Act were eliminated, the legislature would not have been satisfied with what remained."24 After analyzing the legislative history of the statute, the court concluded that the General Assembly's intent to regulate the state's pension liabilities predominated and that this intent would be frustrated by holding the entire act invalid..$^{25}$ The court held that, despite the presence of an inseverability clause, the unconstitutional provision was severable from the rest of the statute. ${ }^{26}$

In spite of the courts' tendency to analyze inseverability clauses in the same way as severability clauses, there are some indications that inseverability clauses may carry more dispositive weight than severability clauses and may be applicable without exploring legislative intent or history. In Zobel $v$ Williams ${ }^{27}$ the Supreme Court, after holding a portion of an Alaska statute unconstitutional, considered whether the provision could be severed from the remainder of the statute. Rather than look to legislative history or the statute's structure to discern legislative intent, the Supreme Court noted that it "need not speculate as to the intent of the Alaska Legislature; the legislation expressly provides that invalidation of any portion of the statute renders the whole invalid.."28 Although the Court ultimately remanded the inseverability determination of the statute to the Alaska courts, the Court's language is more deferential to the inseverability clause than its attitude towards severability clauses in Alaska Airlines ${ }^{29}$ and Jackson..$^{30}$

${ }^{2 s}$ Id at 184 (citations omitted).

${ }^{25} \mathrm{Id}$ at 185.

${ }^{26}$ Id. See also Commonwealth $v$ Kuphal, 347 Pa Super 572, 500 A2d 1205, 1218 (1985) (Spaeth dissenting) (examining legislative history for evidence that legislature intended inseverability clause to create inseverable statute); State Board of Polygraph Examiners $v$ Hamilton, 594 SW2d 833, 835 (Tex Civ App 1980) (refusing to apply a statute's inseverability clause because the legislature only intended the clause to apply to provisions rendered invalid by courts, not those preempted by legislative action).

${ }^{27} 457$ US 55 (1982).

${ }^{23}$ Id at 65.

${ }^{2}$ Alaska Airlines, 480 US at 686 ("[T]nclusion of such a [severability] clause creates a presumption that Congress did not intend the validity of the statute in question to depend on the validity of the constitutionally offensive provision ... unless there is strong evidence that Congress intended otherwise.").

${ }^{30}$ See text accompanying note 11 . 
In addition, some states that have codified their severability law have included statutory language implying that, whereas severability clauses raise only a presumption, inseverability clauses may be dispositive of the severability question. The Indiana Code, for example, provides:

(a) If any provision of this code as now or later amended or its application to any person or circumstances is held invalid, the invalidity does not affect other provisions that can be given effect without the invalid provision or application. (b) Except in the case of a statute containing a nonseverability provision, each part and application of every statute is severable. If any provision or application of a statute is held invalid, the invalidity does not affect the remainder of the statute unless: (1) the remainder is so essentially and inseparably connected with, and dependent upon, the invalid provision or application that it cannot be presumed that the remainder would have been enacted without the invalid provision or application; or, (2) the remainder is incomplete and incapable of being executed in accordance with the legislative intent without the invalid provision or application. ${ }^{31}$

Thus, all Indiana statutes are severable unless they contain inseverability clauses or severability would be inconsistent with legislative intent or the severed statute would lack autonomy. The Code does not include a limitation, such as the one in subsection (b)(1), that would require an examination of legislative intent for "non-severability" clauses. This is significant because it implies that, when a statute supplies an inseverability clause, the clause is inseverable and no further examination of legislative intent or purpose is required.

\section{INSEVERABILITY ClAUSES: A RECIPE FOR COMPROMISE}

The previous Part outlined the courts' practice of analyzing inseverability clauses in the same manner as severability clauses. This Part will outline the differences between severability and inseverability clauses and propose that courts stop analyzing the two clauses in the same way.

\footnotetext{
${ }^{31}$ Ind Code Ann $\S 1-1-1-8$ (West 1981) (emphasis added). See also DC Code Ann $\S 49-$ 601(a)-(b) (Michie Replacement Vol 1990).
} 
A. Boilerplate or Deliberate?

The reason most commonly given for the courts' practice of second-guessing severability clauses is that the clauses are boilerplate provisions inserted into statutes by legislatures without thought or deliberation. ${ }^{32}$ Because of the often complex, multiissue bills passed by legislatures, severability clauses are inserted to address a remote contingency: a court holding a small part of the overall statutory scheme invalid might dismantle farreaching and elaborate omnibus legislation. Although severability clauses are included in statutes quite frequently, legislative drafters are nonetheless aware that courts do not show these clauses much deference. ${ }^{33}$ Legislators themselves acknowledge the perfunctory nature of severability clauses and their inclusion in legislation is generally uncontested. One congresswoman, for example, presumed that no floor debate was necessary to discuss the inclusion of a severability clause because such clauses were so commonplace:

This is a standard "boilerplate" severability clause; similar language has been included in a wide variety of laws including: The Emergency Unemployment Compensation Amendments of 1993, the Americans with Disabilities Act, the Civil Rights Restoration Act, the Fair Labor Standards Act, the Education for Economic Security Act, and the Comprehensive Drug Abuse Prevention and Control Act. ${ }^{34}$

Indeed, as Congressman Frank stated when he introduced a severability clause into a different bill: "This is fairly routine ... this is I think agreed upon by all the parties, to explicitly put in the kind of severability clause that sometimes is made explicit . . . . This is just boilerplate severability." ${ }^{35}$ Congressman Frank acknowledged that severability clauses are not always included in legislation "explicitly" because there is an implicit assumption

${ }^{32}$ See, for example, Laurence $\mathrm{H}$. Tribe, The Legislative Veto Decision: A Law By Any Other Name?, 21 Harv J Leg 1, 22 (1984) ("a boilerplate severability clause (of the sort most laws contain)"); Nagle, 72 NC L Rev at 239-44 (cited in note 5) (arguing that clauses are frequently not boilerplate).

${ }^{3}$ See Lawrence E. Filson, The Legislative Drafter's Desk Reference $\$ 13.6$ at 163-64 (Cong $Q$ 1992) (" $[T \mathrm{t}$ is debatable whether such a clause can affect the outcome of a judicial determination."); Norman J. Singer, 2 Sutherland Statutory Construction $\$ 44.08$ at 521 (Clark, Boardman 5th ed 1993) ("Because of the very frequency with which it is used, the separability clause is regarded as little more than a mere formality."); Thomas $R$. Haggard, Legal Drafting in a Nutshell 313 (West 1996) ("[S] everability provisions . . . are generally unnecessary in legislation because the courts ... have the power to ignore a severability provision .... Nevertheless, most statutes contain a severability clause.").

${ }^{34} 140$ Cong Rec H 3117 (May 5, 1994) (statement of Representative Slaughter).

${ }_{35} 134$ Cong Rec H 3645 (May 25, 1988) (emphasis added). 
of severability to start with. As one congressman pointed out when he submitted a bill without a severability clause:

No severability or nonseverability provisions were included in the bill, but it is the intention of the conferees that any judicial determination regarding the constitutionality of the bill be applied severably to the legislation. This is consistent with the current rule of thumb regarding constitutional challenges to any law that is silent on the issue of severability. $^{36}$

Thus, the severability clause itself is understood by legislators as an innocuous provision that is not likely to be heeded by courts. As one court pointed out, "[t]he Act in question contains a 'saving clause' which it seems customary nowadays to insert in all legislation with the apparent hope that it may work some not quite understood magic."

Furthermore, while the severability clause is rarely dispositive, it may prove useful to courts in the easy case and, even if it is ignored by courts entirely, ${ }^{38}$ it is hard to imagine how such a clause could be harmful. In a 1989 Senate debate over a proposed severability clause in a child-care bill, Senator Hatch, acknowledging that the clause presented a potential benefit with minimal risks, commented that "good draftsmanship, good legislative draftsmanship, smart legislative draftsmanship . . . mandates putting a severability clause in the legislation." 39 This demonstrates that severability clauses are included with little discussion or deliberation. In the same debate, Senator Mitchell pointed out that the clause was so standard that "a severability provision exists in over 63 Federal laws."

Inseverability clauses, on the other hand, are anything but boilerplate. ${ }^{41}$ They are infrequently included in legislation, which

s 142 Cong Rec H 2974 (Mar 28, 1996) (statement of Representative Solomon).

${ }^{37}$ Kapaun v Federal Land Bank of Omaha, 64 SD 635, $269 \mathrm{NW} \mathrm{564,} 565$ (1936), quoted in 2 Sutherland Statutory Construction $\$ 44.08$ at 521 (cited in note 33).

is See Buckley $v$ Valeo, 424 US 1, 108-09 (1976) (finding a statute severable without even mentioning the statute's severability clause).

135 Cong Rec S 7441 (June 23, 1989).

6 Id. See also Nagle, 72 NC L Rev at $240 \mathrm{n} 181$ (cited in note 5):

Members of the legislature themselves sometimes refer to 'usual' or 'boilerplate' severability clauses. See 134 Cong. Rec. 12,280 (1988) (statement of Rep. Frank) (describing clause as "just boilerplate severability"); H.R. Rep. No. 988, 91st Cong., $2 d$ Sess. 49 (1970) (describing section as "the usual separability provision in legislation")....

41 Filson, Drafter's Desk Reference $\$ 13.6$ at 164 (cited in note 33) ("A typical severability clause is pure boilerplate .... Note, however, that the question of whether courts would feel compelled to honor [an inseverability clause] is still up in the air."). 
should alleviate any assumptions by courts that they are inadequately considered before being passed. In addition, when inseverability clauses are proposed, they are strategically designed to ensure that the legislation does not exist without its most fundamental provisions. Consequently, the inclusion of an inseverability clause is usually accompanied by extensive debate. For example, in the Senate floor debate referred to in the previous paragraph, Senator Helms opposed Senators Mitchell and Hatch and introduced an inseverability clause because he anticipated a constitutional challenge to a provision providing benefits for religious day care. Helms wanted to ensure that day-care benefits would not exist unless religious day-care programs could share in the benefit. If the religious day-care provision were held unconstitutional, Helms preferred that Congress revisit the entire child-care issue rather than have the tax code include a childcare benefit that failed to include religious child care. ${ }^{42}$ The inseverability clause was submitted, not as boilerplate language, but in a deliberate attempt to preserve a provision Helms felt was integral to the bill.

A similar debate surrounded the proposed inclusion of an inseverability clause in the proposed Balanced Budget and Emergency Deficit Control Act of $1985 .^{43}$ Among the many controversial elements in the bill, which sought to achieve a balanced budget, was a provision that gave budget supervisory powers to a merged entity of the Congressional Budget Office ("CBO") and the Office of Management and Budget ("OMB"). In light of the partisan dynamic between the President and Congress at the time, the joint participation of congressional and executive agencies was a central feature of the bill. Anticipating a potential constitutional challenge to CBO participation on separation of powers grounds, the House passed a version of the bill that included an inseverability clause. ${ }^{44}$ As Congressman Panetta pointed out at the time:

If you allow severability and the CBO role is found to be unconstitutional, then it leaves it up to the OMB, and it, in essence turns our power entirely over to the President and his

${ }^{42} 135$ Cong Rec S 7439-40 (June 23, 1989). See also, for example, S Rep No 41, 103d Cong, 1st Sess 50 (1993) (Report of Committee on Rules and Administration providing inseverability clause for Congressional Spending Limit and Election Reform Act of 1993, to be activated if chosen provision invalidated).

${ }^{43}$ HJ Res 372, 99th Cong, 1st Sess, in 131 Cong Rec H 9834-68 (Nov 6, 1986).

4t The final version of the bill, which provided the Comptroller with expanded budget powers, was ultimately held unconstitutional in Bowsher v Synar, 478 US 714 (1986). 
agency. That is the issue at stake in terms of why we built inseverability in . . . . ${ }^{45}$

For Congressman Panetta, maintaining a congressional role in the deficit reduction process was a key feature of the legislation. The Act, without the CBO, would include an inadequate check on the executive powers, and the Panetta camp refused to support it. Those opposed to the inseverability clause, however, did not see CBO involvement as a crucial factor and were willing to have the remainder of the Act stand as law even if the CBO's role were held unconstitutional: "[W]e do not want the whole process that we have labored on so hard now to collapse because one provision is held to be unconstitutional. ${ }^{.46}$

\section{B. Limiting Court Powers}

By failing to distinguish between severability and inseverability clauses, the courts ignore the differences in the messages that the two clauses communicate. The clauses are not mirror images of each other; they say different things.

A severability clause does not prohibit courts from invalidating the remainder of the statute because judicial review authorizes courts to declare statutes unconstitutional. ${ }^{47}$ Since a severability clause cannot permissibly limit the scope of the courts' powers of judicial review, all the clause can do is instruct courts that when they hold a provision invalid they are not required to invalidate the whole statute. Through a severability clause, the legislature tells courts that it does not consider the various statutory provisions inextricably linked. Ultimately, the court must determine how far the unconstitutional provision extends and whether the remainder constitutes a fully functioning statute.

When applying inseverability clauses, on the other hand, the courts' exercise of the power is restricted insofar as the court is instructed to invalidate the whole statute if it determines it must invalidate some part. Thus, the clause communicates the legislative command that the statute's existence as a law is contingent on its existence as a whole. The court must carry out this legislative command, regardless of its opinion of the relationship between the invalid provision and the remainder of the statute.

\& 131 Cong Rec H 9866 (Nov 6, 1986), and see statements of Representatives Gephardt and Brooks, 131 Cong Rec H 9866-67 (Nov 6, 1986).

46 131 Cong Rec H 9866 (Nov 6, 1986) (statement of Representative Lott).

${ }^{4}$ See Nagle, 72 NC L Rev at 237 (cited in note 5). 
Read in this light, the two clauses convey very different messages: one suggests to courts what they should but are not required to do; the other tells the courts what they must do. By applying the same analysis to both, courts fail to acknowledge the fundamental differences in the messages communicated by severability and inseverability clauses.

\section{Preserving the Deal}

Aside from being deliberately drafted into legislation, inseverability clauses serve a key function of preserving legislative compromise. Much commentary points out that legislation is the articulation of a legislative deal..$^{48}$ But a compromise is of no value unless there is a mechanism to ensure the compromise's durability, that is, a way of preventing one party to the compromise from benefiting from the deal without upholding its share of the bargain. ${ }^{49}$

An inseverability clause is a useful enforcement mechanism for legislative compromise because it binds the benefits and concessions that constitute the deal into an interdependent whole. In the debate mentioned above, for example, Senator Helms was unwilling to support the child-care bill unless it provided support for religious day care. If Helms's opponents had agreed to the religious day-care provision, there was a strong possibility that the provision would not have withstood a constitutional challenge. ${ }^{50}$ If the provision had been struck down and held severable, the compromise would have been unenforceable. Helms's opponents would have had their child-care benefit, and the religious daycare provision would have been a thing of the past. By making his support for the bill contingent on such an inseverability clause, Helms was entrenching the legislative deal and ensuring that there would be the compromise version of the bill or no version. The inseverability clause thus binds all the elements of the deal together.

Severability clauses, on the other hand, are not tools of legislative compromise. ${ }^{51}$ Legislators include them to ensure that

\footnotetext{
${ }^{4}$ See, for example, William M. Landes and Richard A. Posner, The Independent Judiciary in an Interest-Group Perspective, $18 \mathrm{~J} \mathrm{~L} \&$ Econ 875, 877-84 (1975); Daniel A. Farber and Philip P. Frickey, Law and Public Choice 12-37 (Chicago 1991).

${ }^{49}$ Landes and Posner, $18 \mathrm{~J} \mathrm{~L} \&$ Econ at 877-78 (cited in note 48).

so 135 Cong Rec S 7443-44 (June 23, 1989) (letter from Professor Laurence Tribe).

sI But see Heckler v Mathews, 465 US 728, 734 (1984) (discussing a severability clause that requires provisions to be severed from an entitlement if they are held unconstitutional in order to prevent expanded eligibility for the entitlement from ballooning the budget).
} 
the bulk of the legislation passed will remain intact even if some unanticipated contingency arises. As Senator Hatch pointed out:

Who knows what a future Supreme Court will do? But, in the unlikely event that something in this legislation is unconstitutional, we surely want a severability clause in there so that all of the legislation is not wiped out in a single swoop of the Supreme Court's pen. ${ }^{52}$

Because severability and severability clauses are the default rule and the norm, respectively, the inclusion of an inseverability clause is an affirmative act by a legislature to preserve the coexistence of separate provisions. In settlement agreements and other kinds of contracts, for example, the parties determine that certain provisions are so central to the deal that without them there is no contract. ${ }^{53}$ The inclusion of inseverability clauses in these contracts is intended to preserve such compromises. ${ }^{54}$

In a similar vein, a legislature may pass a bill that, as a result of a legislative deal, contains a balance of corresponding provisions. If the statute includes an inseverability clause, the legislature is saying that the statute is an organic whole of interdependent parts, no one of which should exist without any other. For example, several statutes codifying settlements of Indian claims in return for some form of reparation contain inseverability clauses for this reason and could not have been passed without them. ${ }^{55}$ If court action invalidated the statutory bar on prosecution of their claims, the tribes would have a double benefit: they could receive statutory compensation for their lands and still prosecute claims to recover those same lands. The inseverability clause prevents this outcome.

In Kennedy $v$ Pennsylvania, a state legislature had used an inseverability clause aggressively to gain government-wide support for its actions. ${ }^{56}$ The Pennsylvania legislature approved an across-the-board pay increase to state government employees, in-

${ }^{52} 135$ Cong Rec S 7441, mentioned in Nagle, $72 \mathrm{NC} L$ Rev at 241 (cited in note 5).

" See, for example, Abbott-Interfast Corp v Harkabus, 250 Ill App 3d 13, 619 NE2d 1337, 1343-44 (1993) (noting that some facts of the agreement may be so central that to enforce the remainder would be to create a new agreement); Hill $v$ Names \& Addresses, Inc, $212 \mathrm{Il}$ App 3d 1065, $571 \mathrm{NE2d}$ 1085, 1100 (1991) (noting that parties' specific determination that a term is essential trumps a general contractual severability clause); Arizona $v$ Nucor Corp, 825 F Supp 1452, 1456 (D Ariz 1992) (settlement agreement in CERCLA case contained non-severability provision).

" See, for example, American Can Co v Herpel (Matter of Jackson Brewing Co), 624 F2d 605, 611 (5th Cir 1980) (on remand, district court allowed to consider nonseverability given the nature of the compromise embodied in the agreement).

${ }^{5}$ See, for example, 25 USC $\$ \S 941(\mathrm{~m}), 1734,1749(1), 1760$ (1988 \& Supp 1996).

ts $119 \mathrm{~Pa}$ Commw 24, 546 A2d 733, 738-39 (1988). 
cluding legislators and judges. ${ }^{57}$ Because the state constitution prohibited legislators from voting themselves a pay increase during their current term, the increase for legislators was effective beginning with the next election. ${ }^{58}$ However, in order to gain votes to support the appropriation, the final bill also increased legislators' unvouchered expense accounts for the period prior to the election in the amount of the pay increase. Anticipating a court challenge to the expense account increase, the legislators included an inseverability clause. The clause provided that, were a court to invalidate any provision of the statute, none of the salary increases would be effective, including those for judges. ${ }^{59} \mathrm{Al}$ though the inseverability clause may have been an attempt to pressure judges into holding the expense account increase valid, the Pennsylvania court held the inseverability clause constitutional and valid, even though it affected the judiciary. ${ }^{60}$ While the scruples of the Pennsylvania legislature were questionable, their use of the inseverability clause proved an effective tool for preserving their deal.

Similarly, inseverability clauses are often included in budgetary legislation to ensure that the funding scheme developed is viable. If a court determines that an entitlement's eligibility requirement is invalid, then the funding apparatus supplied by the remainder of the entitlement would become inadequate. For example, in Brookins $v$ O'Bannon, ${ }^{61}$ the Third Circuit considered an inseverability clause that was included in the 1982 Pennsylvania Welfare Reform Act. The Act divided the class of needy persons eligible under the prior law into "chronically needy" and "transitionally needy" persons and continued to provide full benefits to the "chronically needy." The "transitionally needy," however, were limited under the new act to three months of benefits per year. ${ }^{62}$ With the savings generated by reducing benefits to the new "transitionally needy" class, the Act provided for a 5 percent increase in the benefits provided to eligible recipients. ${ }^{63}$ The Act included an inseverability clause that eliminated the 5 percent increase should the distinction between "chronically needy" and

${ }^{57}$ Id at 735.

ss.

Id at 738 .

क Id at 739 .

${ }^{61} 699$ F2d 648 (3d Cir 1983). See also the inseverable statutory provisions discussed in Rebaldo $v$ Cuomo, 1984 WL 48826, *9-10 (S D NY), vacated on other grounds, 749 F2d 133 (2d Cir 1984); Stiens v Fire and Police Pension Assn, 684 P2d 180, 182 n 7 (Colo 1984) (en banc).

${ }^{62}$ Brookins, 699 F2d at 649-50.

$\approx$ Id at 650-51. 
"transitionally needy" be held invalid. ${ }^{64}$ As one legislator pointed out: "We do not want to raid [the] State Treasury. We want to provide an increase in cash assistance allowance to the truly needy as long as those funds are there. ${ }^{165}$

The clause provided an important tool for the legislature to regulate welfare spending by ensuring that the increase in benefits was contingent upon narrowing the scope of eligible welfare recipients. The Third Circuit ultimately did apply the inseverability clause, but only aiter examining the legislative history of the provision. ${ }^{66}$ One can only speculate as to what the court would have done to Pennsylvania's welfare budget had the legislative record lacked any discussion of the Act's inseverability clause.

Thus, by applying the same analysis to inseverability clauses as they apply to severability clauses, courts are denying legislators an effective tool for entrenching a compromise. If courts are only moderately deferential to inseverability clauses, and if the clauses establish no more than a presumption of inseverability, then courts will only apply the clause if there is a clear record in the legislative history. Consequently, legislators will be reluctant to rely on the clause as a tool of compromise for fear that courts will undertake independent determinations of legislative intent despite the statutory mandate of inseverability. This problem will be exacerbated for state legislators because legislative history for state legislation is often difficult to locate and thinly reported. ${ }^{67}$ Occasionally, legislation can be made palatable or effective only by tempering it with various limiting factors or requirements, and the inseverability clause is intended to ensure that these elements remain in the statute. By treating the inseverability clause as if it were only a minor indication of legislative intent, courts are usurping the legislature's role in determining what should remain as an enforceable statute.

\section{A NEW RULE FOR INSEVERABILITY CLAUSES}

The previous Part established that inseverability clauses serve a wholly different function from severability clauses. Therefore, the rule that courts apply to inseverability clauses

$\stackrel{a}{\text { Id. }}$

${ }^{65}$ Id at $651 \mathrm{n} 5$, quoting $1982 \mathrm{~Pa}$ Legis J-House 721 (Mar 24, 1982).

${ }^{65}$ Brookins, 699 F2d at 650-51.

${ }^{67}$ See William H. Page, Interest Groups, Antitrust, and State Regulation: Parker v. Brown in the Economic Theory of Legislation, 1987 Duke L J 618, 647; Jose R. Torres and Steve Windsor, State Legislative Histories: A Select Annotated Bibliography, 85 Law Libr $\mathrm{J} 545,547,550$ (1993). 
should be distinct from that applied to severability clauses. The correct approach to inseverability clauses is to apply their plain meaning. Rather than embarking on an independent exploration of legislative intent, as the courts do for severability clauses, courts should unequivocally invalidate the remainder of a statute if the unambiguous language of the statute so directs.

\section{A. A Public Choice Approach}

The proposed rule can be understood through a theory of statutory interpretation that derives from a contracts approach. Public choice theory tends to view legislation as the product of various interest groups vying for their self-interests. ${ }^{68}$ Legislation therefore is a contract of sorts negotiated between the various parties, that is, between the different legislators and the interest groups with whom they sympathize. According to this theory, legislation is often a compromise between conflicting groups where one group agrees to support another group's proposed legislation in return for some modifications in the underlying bill or for support on another issue. Consequently, the legislation may lack a cohesive focus because different portions of the bill are included to placate different groups.

An inseverability clause provides legislators with a tool for enforcing these compromises because one group may be willing to support a piece of legislation only if it can be assured that particular limitations or provisions will be included in the final bill. ${ }^{6}$ Senator Helms, for example, could agree to support a child-care entitlement on the condition that religious day-care centers were eligible for the benefit. ${ }^{70}$ His insistence on an inseverability clause testifies to the clause's important role in entrenching a compromise.

Similarly, after the Chadha decision there were initiatives in Congress to include inseverability clauses in statutes with legislative veto provisions. ${ }^{71}$ The inseverability clause would enforce durable legislative deals whereby various federal actions mandated by statute could not be undertaken unless Congress had the power to veto the action. If the Court, as it did in Chadha, held such an attempt at legislative veto unconstitutional, then the inseverability clause would cause the entire statute to fall

\footnotetext{
${ }^{65}$ See generally Farber and Frickey, Public Choice at 12-37 (cited in note 48).

See Part II.C.

${ }^{70} \mathrm{Id}$.

${ }^{7}$ See Abner J. Mikva and Eric Lane, Legislative Process 76 (Little, Brown 1995).
} 
rather than leave the statute to function free from any legislative check on its application.

It is, however, imaginable that in many instances a sparse record will provide an inadequate background as to the negotiation and compromise behind an inseverability clause. Alternatively, because of the conflicting interests that influence the legislation, the legislative history often provides conflicting evidence of legislative intent or purpose. ${ }^{72}$ As such, a rule that failed to defer to the plain meaning of the inseverability clause would, in effect, undermine the clause's function as a legislative tool for enforcing compromise. Courts would be free to speculate as to legislative intent and purpose in the absence of an informative legislative history.

Applying the plain meaning of inseverability clauses without second-guessing legislative intent helps facilitate durable legislative compromises. ${ }^{73}$ If courts are able to examine legislative intent and to speculate whether the legislature would have passed the legislation without the invalid provisions, there is a great likelihood that legislative deals will be undermined or shortlived. If courts will sever provisions that were passed as interdependent elements, legislators will be less willing to enter into compromises: they will fear that the issues they concede will outlive the issues they support. That is, the costs of the deal might outlive its benefits. ${ }^{74}$ Severability clauses, on the other hand, do not enforce the legislative compromise; they protect the passage of complex omnibus clauses. A strict plain meaning rule of severability clauses, therefore, would not help to preserve a legislative deal. If anything, the severability clause attempts to undo legislative deals by instructing courts to uphold the balance of a statute even when portions of the legislative deal have been struck down.

Nevertheless, courts' deference to the plain meaning of inseverability clauses should not be unlimited. If giving effect to an inseverability clause would result in overstepping the bounds of

${ }^{22}$ A rule that required a clear and unambiguous statement in the legislative history to demonstrate that inseverability was really intended when an inseverability clause is included would, presumably, be subject to the same problem. Any legislative history found to support severability would place the entire question in doubt and return the issue to the courts to decide.

${ }^{23}$ An inseverability clause that is included in a public referendum, however, is not part of a legislative compromise and should not be construed according to its plain meaning. See, for example, Surrat v Prince George's County, 320 Md 439, 578 A2d 745, 749 (1990) (refusing to apply an inseverability clause that was included in a public ballot because its effects were not explained to voters).

" Landes and Posner, $18 \mathrm{~J} \mathrm{~L} \mathrm{\&} \mathrm{Econ} \mathrm{at} \mathrm{877-78} \mathrm{(cited} \mathrm{in} \mathrm{note} \mathrm{48).}$ 
legislative or judicial authority, then the clause should not be followed. For example, in Legislative Research Commission $v$ Brown, an inseverability clause provided that if a Kentucky legislative veto provision were held invalid, then the state's executive department would not be permitted to issue regulations unless the state's general assembly was in session..$^{75}$ The clause was intended to force the courts to uphold the veto in order to avoid crippling the executive branch's powers. The Kentucky Supreme Court wisely refused to apply the inseverability clause and held that the clause "unconstitutionally limit[ed] and interfer[ed] with the governor's mandated duties."76 Thus, legislatures are free to construct a legislative compromise through inseverability clauses provided they do not attempt to force courts to fashion unconstitutional holdings. ${ }^{77}$

\section{B. An Inseverability Canon}

In order to prevent courts from undermining the legislative compromises that are sealed by inseverability clauses, this Comment calls for a new interpretive canon for inseverability clauses.

\section{A clear statement rule.}

The proposed rule would function like a clear statement rule. Clear statement rules are generally defined by polarities. On the one hand, there is a presumption that cannot be overcome unless the legislature has provided a clear statement otherwise. On the other hand, a clear statement rule must also define what statutory language would be sufficient to constitute a "clear statement" to overcome the court's presumption. For example, in Atascadero State Hospital v Scanalon, ${ }^{78}$ the Court articulated a clear statement rule for congressional abrogation of states' Eleventh Amendment immunity from suit in federal courts. The Court held that, when the statutory language is ambiguous as to abrogation, it will not attempt to divine whether Congress intended to abrogate. The presumption of immunity created a "requirement . . . that Congress unequivocally express its intention to abrogate . . . by making its intention unmistakably clear in the language of the statute. ${ }^{.79}$

\footnotetext{
${ }^{75}$ 664 SW2d 907, 919-20 (Ky 1984).

${ }^{76}$ Id at 920.

"See also Kennedy, 546 A2d at 738-39, discussed in text accompanying notes 56-60.

${ }^{78} 473$ US 234 (1985).

${ }^{79}$ Id at 242.
} 
The codified statutory construction rules in the Indiana Code, for example, illustrate how such a presumption would work. ${ }^{80}$ The rule presumes severability regardless of whether a severability clause is included in the statute. However, once the legislature has included an inseverability clause, a clear statement of legislative intent has been provided and the courts must therefore defer to the unambiguous language in the clear statement. ${ }^{81}$ Such a rule would prevent courts from second-guessing inseverability clauses. The proposed rule recognizes that the inclusion of an inseverability clause is a deliberate act of the legislature to enforce a legislative compromise and to ensure that the provision and the remainder of the statute operate in tandem.

There is one modification, however, from the clear statement model. Absent a clear statement in an inseverability clause, the default rule is not severability but rather a presumption of severability. The classic clear statement rule contains a default rule that can only be overcome by a clear statement. The default in the proposed rule for inseverability clauses, however, does not limit findings of inseverability to the presence of inseverability clauses. Whether or not the statute contains a severability clause, the presumption of severability can be overcome by legislative history or statutory structure indicating that the legislative intent was for inseverability. ${ }^{82}$ An inseverability clause, by contrast, provides a clear statement that unmistakably requires courts to invalidate the statute's remainder.

\section{A statutory device.}

As with substantive canons, courts often choose to interpret and apply particular statutory devices in a consistent manner. Courts will often apply time limitations and deadlines, for example, according to the statute's strict plain meaning. In United States $v$ Locke ${ }^{83}$ the statutory deadline for a mining rights application was "prior to December 31," even though similar deadlines generally extended to the end of the year with language such as "on or before December 31." The Supreme Court read the statute literally and held that an application filed on December 31 was too late. This can be read as a rule of strict construction for dates and deadlines included in statutes. As Justice Marshall wrote, "[f]iling deadlines, like statutes of limitations, necessarily oper-

${ }^{8}$ Ind Code Ann $\S 1-1-1-8$ (West 1981), discussed in text accompanying note 31. See also DC Code Ann $\$ 49-601$ (a)-(b) (Michie Replacement Vol 1990).

${ }^{\text {s1 }}$ See Ind Code Ann $\S 1-1-1-8$.

Ind Code Ann \$ 1-1-1-8(b) (1)-(2).

$\therefore 471$ US 84 (1985). 
ate harshly and arbitrarily with respect to individuals who fall just on the other side of them, but if the concept of a filing deadline is to have any content, the deadline must be enforced.".84

Thus, while the severability clause canon examines legislative intent in spite of the clause's language, the canon for reading inseverability clauses should read the clauses strictly according to their plain meaning-in short, the inseverability clauses should be dispositive. To paraphrase Justice Marshall, if the inseverability clause is to have any content, its plain meaning must be applied.

This raises the potential, however, of an absurd result where an inseverability clause is activated by a very minor holding of invalidity. In Rebaldo $v$ Cuomo ${ }^{85}$ for example, an amendment to New York's Public Health Law prohibited New York's public hospitals from charging any of the insurance carriers less than a specified rate. The law contained an inseverability clause that invalidated the entire statute if any payor was charged below the specified rate. The clause was intended to restrain the major payors like Medicare, Medicaid, and Blue Cross from obtaining cheaper rates. However, the court noted that "a literal construction of the language would lead to the absurd result that 'a single uninsured patient . . . would invalidate the statute" if that person paid a hospital bill below the specified rate. ${ }^{86}$ Although the Rebaldo court decided the case on other grounds, the inexpertly drafted inseverability clause might have led to an absurd result. ${ }^{87}$

However, as the Court in Locke noted, it is often necessary to let some seemingly harsh results stand in order to preserve the

\footnotetext{
Id at 100-01.

Es 1984 WL 48826, *9-10 (S D NY), vacated on other grounds, 749 F2d 133 (2d Cir 1984).

${ }^{88}$ Id at $* 9$.

${ }^{87}$ There is another potential side effect of a strict plain meaning rule: courts may attempt to avoid its occasional harshness by questioning the inseverability clause's applicability to the stricken provision. In Pennsylvania v Kuphal, $347 \mathrm{~Pa}$ Super 572, 500 A2d 1205,1208 (1985) (Beck concurring), for example, an inseverability clause provided that "subsection (a)" of a 1980 act amending the state sentencing guidelines was inseverable from the remainder of the act. The Kuphal court refused to apply the inseverability clause because the clause's language was ambiguous as to whether "subsection (a)" referred to a subsection in the statutory guidelines or a subsection of the 1980 act as passed. See also Jones $v$ Lowe, $611 \mathrm{~S} 2 \mathrm{~d} 345,347$ (Ala 1992) (holding that an inseverability clause was only activated if a court found the provision "invalid," not if it held that the provision did not apply); Blake $v$ Big B, 613 S2d 1265, 1266 (Ala 1993) (recognizing "a material distinction between a declaration of unconstitutional application of a statute . . . and a holding declaring the statute itself unconstitutional. Thus, while the latter would invoke application of a nonseverability clause, the former would not."). However, this phenomenon is likely to be rare because courts are constrained by the actual and generally unambiguous language of the inseverability clause.
} 
power of inseverability clauses generally. Although courts are often reluctant to enforce what appear to be absurd results, by generating a rule that strictly applies the plain meaning of inseverability clauses, courts will force legislatures to draft the clauses with greater precision. As Justice Scalia wrote, "we have an obligation to conduct our exegesis in a fashion which fosters [the] democratic process." ${ }^{\text {B }}$ By applying the plain meaning, courts are not only forcing legislatures to craft inseverability clauses with greater care, they are also providing legislatures with effective tools for passing legislation by creating durable compromises.

\section{CONCLUSION}

Applying the severability clause analysis to inseverability clauses fails to address the distinct nature of inseverability clauses. This Comment demonstrates that the dynamic in inseverability clauses is different from that of severability clauses and calls on courts to apply the strict plain meaning of inseverability clauses. The presence of an inseverability clause evidences a legislative compromise and a deliberate attempt by the statute's drafters to inseverably link statutory provisions. An exploration by courts of the legislative intent behind an inseverability clause will necessarily undermine the clause's ability to enforce legislative compromise. By deferring to the plain meaning of inseverability clauses, courts will encourage the legislative process by preserving an effective tool for enforcing legislative deals.

ss United States v Taylor, 487 US 326, 346 (1988) (Scalia concurring) (advocating interpretation of plain statutory text rather than reference to legislative history). 
